\title{
"THE STRATEGY AND PSYCHOLOGY OF RESISTANCE IN A CONTEMPORARY KASHMIRI NOVEL IN URDU”
}

\author{
Muhammad Awais Bin Wasi, Muhammad Sheeraz \\ ${ }^{1}$ Department of English, Riphah International University, Islamabad, Email: awais.wasi@riphah.edu.pk \\ ${ }^{2}$ Department of English, International Islamic University, Islamabad, Email: m.sheeraz@iiu.edu.pk
}

\begin{abstract}
:
The sociopolitical milieu of post-1989 Kashmir heavily influenced the creative imagination. Multiple literary narratives have recounted the everyday life in Kashmir which is often seen as South Asia's nuclear flash point.Severalliterary works have also been brought out in the Urdu language. In this paper, drawing uponBarbara Harlow's framework of resistance literature and Jeanette Lawrence and Agnes Dodds's theorization of the psychology of resistance, we argue that Nayeema Ahmad Mehoor's Urdu novelDahshat Zadiis an example of Kashmiri resistance literature.Thepaper is also an attempt to understand how the contemporary Kashmiri writing in Urdu is linked with the broader resistance movement in Kashmir. Reconciling the representative strategy of resistance literature, as proposed by Harlow and others, with those employed by a Kashmiri writer, the study suggests that the patterns and purposes of resistance are often similar across the linguistic and geographical divides.
\end{abstract}

Keywords:

Kashmiri Literature, Resistance Literature, Nayeema Ahmad Mehjoor, Urdu

Article Received: 18 October 2020, Revised: 3 November 2020, Accepted: 24 December 2020

\section{INTRODUCTION AND BACKGROUND}

Drawing upon Barbara Harlow's framework of resistance literature, Jeanette Lawrence and Agnes Dodds's theorization of the psychology of resistance, and the South American conceptualization of the genre of testimonio,this paper analyzes Nayeema Ahmad Mehjoor's novelDahshat Zadi. We show how this work of fiction is linked with the body of resistance literature produced in other geopolitical contexts of the world, including Africa, South America, and South Asia. First of its nature, this paper is alsoa step towards identifying the key features of resistance present in Kashmiri literature in Urdu. By exploring the literary strategies of resistance employed in the narrative, we also link this novel with the broader resistance movement in Kashmir where people have gone through a constant psychological and physical torture in the wake of perpetual violence.

Resistance is all around us. It arises in international arenas as disputes about territory, wealth and national interests; in national arenas as clashes between political movements and popular demands for legislative change; and in family as intergenerational disputes and abuse...Struggles in India, Egypt and Spain are globally available in daily news. (Lawrence \& Dodds, 2017, p. 67-68) Imagination can also be seen as a way of resistance (see e.g., Tateo, 2017). Although the so-called tech-revolution with its broadcasting gift of social media has many it easier to voice opposition, writing as a form of resistance (see e.g., Flynn, 1996) is still more systematic as well as convincing medium of resistance. In this paper, we will show how a Kashmiri novel in Urdu takes employs various strategies of resistance to not just reflect the history and psychology of Kashmir and Kashmiris but also to convince its readers of the truth of the narratives it portrays and to contribute towards a better future of the people of the region. This way the novel is engaged in an intentional and future-oriented resistance. "The intentional dimension of resistance is ... the conscious activity of a human agent" (Lawrence \& Dodds, 2017, p. 71). First step towards this is the novel's embracing a clear political position.

...the theory of resistance literature is in its politics unlike narrow framework of criticism inspired by the mantle of neutrality and objectivity 
in the western tradition. It originates in and responds to a particular mode of politics and can only refer to actions which function against the apparatus of the state. (Harlow, 1987, p. 30)

Taking togetherthe politics thisliterary narrative is a part of, its resistance to the occupation, allusions to the local sociopolitical history, rootedness in the ideological and material conditions it is produced in, its heteroglossic nature, its representation of a collective issue, and its contribution tothe liberation struggle, Dahshat Zadi is a narrative of Kashmiri resistance.

Jammu and Kashmir's literary historyspans over centuries. A large bulk of literature is available in languages such as Sanskrit, Persian, Kashmiri, Urdu, Hindi, Punjabi and English. Some of the literary traditionsthis literature deals with are Hindu and Muslim philosophical debates, mysticism, romanticism, social realism and resistance.

Urdu is the official language of the state of Jammu and Kashmir,and therefore, it enjoys the state patronage. Most of the Kashmiri writers have opted for this language for their creative expression composing their works notably in the genres of novels, short stories and poetry. The famousKashmiri Urdu novelist, Rahman Abbas,rightly asserts that"Urdu language has for long been nurtured by the Kashmiri writers" (Writers must Register Protest, Dec 7, 2017). Like it is the case with all the literatures of the world, Kashmiri Urdu literature is also influenced heavily by the sociopolitical condition that it is produced in. Many contemporary Urdu writers in Kashmir have depicted the Post-1989 realities which are frequented with armed clashes, violence and trauma. Such notable works include:Ailaan Jari Hae(the announcement continues), an anthology of 22 short stories by Ghulam Nabi Shaid;Qadam Qadam Tazeer(punishment at every step), a collection of short stories by Maqbool Sahil;Shabistaan-e-Wajood (chamber harem of existence), a prison memoir by Maqbool Sahil;Nigah-e-Anjum (eye of the star), an autobiography of Zumurda Habib, a human rights activist;Qaidi No. 100 (prisoner number 100) by
Zamurda Habib; and Dahshat Zadi (the daughter of terror), a novel by Nayeema Ahmad Mehjoor. This paper explores Mehjoor's literary strategies of resistanceto portray a realistic picture of the private and public and family and national lives of the Kashmiris. With resistance as its dominant theme, the novel becomes a representative case for Kashmiri Urdu resistance literature.

The earliest footprints of Urdu language in Kashmir can be traced to the people who came here from Punjab and other parts of the world and worked on important government positions. Their interaction with the local people paved the way for its introduction in Kashmir. The Dogra rulers later decided to patronize this language. In 1889, Maharaja Pratap Singh introduced it as the official language of the state of Jammu and Kashmir (Premi, 1992, p. 21) and paved the way for Urdu literature in Kashmir or by the Kashmiri writers living outside Kashmir in various cities of the subcontinent, especially in Lahore.

Maharaja Ranbir Singhpromoted this language by getting many books translated into Urdu from Arabic, Persian and other languages ( $\mathrm{p}$. 19). The Maharaja alsoestablished the first press in Kashmiri,Badia Balas, and launched the first newspaper with the same name that was published both in Perso-Arabic and Devanagari scripts (p. 19). The contributions of Kashmiri writers to Urdu language and literature are in diverse range of genres i.e., historical chronicles as wells as novels, short stories, poetry, and criticism. In history, Muhammad Din Fauq's Tareekh-eKashmir(history of Kashmir) is considered an authentic account of Kashmir's past. Fauq's contribution in creating political consciousness among the people of Jammu and Kashmir through Urdu newspapers hold significance in equal measures. The other pioneering prose writer was Har Gopal Khasta who wrote Guldast-e-Kashmir (bouquet of Kashmir).

The list of Kashmiri writers of Urdu literature is long and cannot be reproduced here. However, the following Kashmiri writers are considered significant for their literary achievements: Talib Kashmiri, Kiship Bandhu, 
Rasa Jawdani, Abdul Ahad Azad, Prem Nath Bazaz, Malik Raj Saraf, Prem Nath Pardesi, Mir Ghulam Rasool Nazki, Jeep Kaifvi, Kashmiri Lal Zakir, Tej Bahadur Bahan, Hamidi Kashmiri, Pashkar Nath (p. 7). Similarly, the list of Urdu writers of Kashmiri origin spent their lives elsewhere is also important. The most prominent among them are:Allama Muhammad Iqbal, Chiragh Hassan Hasrat, Saadat Hasan Manto, Niaz Fateh Puri, Munshi Prem Chand, and Qudratullah Shahab (p. 7).

As far as the connection of Kashmiri Urdu literature with the themes of resistance is concerned, some of the earliest works are those produced under the influence of the Progressive Writers Movement which swept the Indian subcontinent in the middle of twentieth century. These works challenged the oppression of Dogra's despotic rule and its curbs on people's fundamental rights.

\section{Dahshat Zadi}

Dahshat Zadi(2007) is the story of a Kashmiri family that is caught up in violence ridden turbulent phase of Kashmir's modern history which started in 1989. The story mainly revolves around a Kashmiri female journalist, and her pleasant relations with her sisters, father, neighbors and colleagues but estranged ties with her husband. The author is the noted Kashmiri journalist and her work is largely autobiographical.

All the sisters including the protagonist gather at their father's house right after a bomb blast at the residence of a police officer that triggered a wave of violence grippingthe Kashmir valley. Instead of usual gossiping, they start discussing the blast from different angles. One of the sistersis over-joyed at the newsof the blast. However, their father remains silent.

The novel narrates the turbulent relations of the protagonist with her husband due to his authoritarian approach, protecting the fighters and strangers at their house and taking the risk of army crackdown. Numerous relatives also keep staying at his house for many days making the small house congested and turning it into a messy place with everything at sixes and sevens.

The novel also portrays the painful plight of the wives and mothers who have lost their husbands and sons. In Kashmir, they are now termed as Half Mothers and Half Wives as they are unaware whether or not their husbands and sons are alive. The character of Fareeda whose husband was dragged to somewhere despite her sky high screams and pleas to the security forces that he was not a militant represents a half-wife while Sadia represents the distress and agony of half mothers in Kashmir.

Auntiji is another important character in the novel who is known throughout her neighborhood for her cheerful disposition. Her son is picked up by the security forces and after a few days her mutilated dead body was found near her house.

The novel also portrays the trust deficit between Kashmiri pandits and Kashmiri Muslims and their displacement from the valley due to life threats. Neena, a close friend of the protagonist leaves her home one night after informing her closest friend. Moreover, there are some characters like Shaista and Saira who get killed as they were the informers of Indian security forces. The novel also shows the radio station in which the protagonist is working. The radio propagates the statist narratives as it is considered the mouthpiece of India.

The novel is divided into nine sections. Each section starts with one liner description of some very significant incident which shapes further sequence of events in Kashmir. For instance, the first section starts with this statement:

September 18, 1988: The house of the Deputy Inspector General of Police was attacked by a gunman in Rajbagh. He was later killed by security guards during a scuffle. The eruption of the armed movement led to mass processions and demonstrations across the Kashmiri Valley. (Mehjoor, 2007, p.3)

Similarly, the other sections begin with the brief descriptions of other important incidents in the 
post-1989 Kashmir. They include: the appointment of Bharatiya Janata Party (BJP) leader Jagmohan Malhotra as Governor of Jammu and Kashmir to quell the mass uprising; thousands of the youth crossing the Line of Control (LoC) to get training from Pakistan; displacement of Kashmiri Pandits from Kashmir valley; abduction Dr Rubaiya Sayeed, the daughter of the then Indian Home Minister Mufti Muhammad Sayeed, by the Jammu and Kashmir Liberation Front (JKLF) fighters; implementation of draconian laws in Jammu and Kashmir such as Armed Forces Special Powers Act (AFSPA), Public Safety Act (PSA), Disturbed Areas Act (DAA), Prevention of Terrorism Act (POTA), etc.;Kunun Pospura gang rape incident by security forces in which around a hundred women were raped in front of their families; acts of harassment and plunder by Ikhwanis, the pro-India militants; the killing of the Director of Doordarshan Television by Kashmiri fighters.

\section{Resistance in Dahshat Zadi}

In this section, we will discuss theways resistance has been voiced in the novel.

As quoted above, Harlow suggests that"the theory of resistance literature is in politics" (1987, p. 30). Incorporating political motif in the narrative is a politicized activity that invokes national consciousness and enhances the feelings of self-identity and existence (p.28). With this frame of reference, Dahshat Zadi seems to be a fitting case of a resistance narrative. It is rooted in the politics associated with the issue of Kashmir and evokes political sympathies in favour of Kashmiris who are victims of oppression. According to the official statist discourse Jammu and Kashmir is an integral part of Indian union and the unrest in Kashmir is India's internal law and order issue. But the novel questions this perspective at many points, and the protagonist argues that India has forcibly snatched Kashmir from its people: “India's new government snatched its (Kashmir's) freedom by conspiring with the Maharaja and getting him to sign the document of its adjacency with India" (Mehjoor,
2007, p. 119).This reference to political history of Kashmir revealing that Kashmir was originally an independent country and was made India's part by conspiracy sets the tone of the novel as a politicized reading.

Similarly, the narrative describes that Kashmiris' yearning for freedom which was heard more clearly in the 1990s is rooted in 1947 i.e., in the partition of the subcontinent. Also, the role of India as a usurper is reaffirmed that this country deprived Kashmir of its freedom through political conspiracies in 1947. And since then, it was kept as a colony through force with its people denied of their fundamental rights. "No relationship survives if it is kept through force. A relationship demands equality with respect and dignity. Three of our generations have seen the different stages of India's colonization. They built this relationship to destroy us, depriving us of our rights and freedom" (p. 30).

So, the very act of taking up the issue as a political dispute and seeing the role of India as a usurper is a politicized act. The novel paints an agonizing picture of Kashmir, caused by the state oppression and violence.

Another characteristic feature of resistance literature is historicity. For Harlow "essential...to the narratives of resistance is the demand they make on the reader in their historical referencing and the burden of historical knowledge such referencing enjoins" (1987, p. 80). The use of history is also meant to keep the record straight. In regions like Kashmir, the rulers' history is different from the people's history. So, when a writer of fiction recounts that history in his work of art, it comes as an expression of resistance against the oppressors. The current issue of Kashmir is rooted in the history of India-Pakistan partition when not only India and Pakistan got independence, but the British suzerainty was lapsed over 562 erstwhile principally states. All except the state of Jammu and Kashmir either joined India or Pakistan in accordance with the partition plan and the wishes of the people of respective states."Jammu and Kashmir became an 
independent state and remained so for about eleven days" (Mehjoor, 2007, p. 119).

The novel makes this historical reference that its people were to get independence in 1947 as the other states did but India usurped the state through the guileful politics."Azadi (independence) perhaps to her also means one's own land, house and identity, the dream of which we have kept alive since 1947' (p. 10).

There is another important historical reference in the novel: "Habba Khatoon holds a significant position in Kashmiri society. She is loved by all. And her poetry is on everyone's tongue. She particularly symbolizes those Kashmiri women who led their lives suffering many hardships" (p. 19). Habba Khatoon (15541609) is a household name in Kashmirfor her lyrical poetry reflecting pain of separation and longing. Though her poetry is about her love with her husband, Yousuf Shah Chak (the king of Kashmir who reigned from 1579 to 1586 ADand was imprisoned by the Mughal rulers till his death), her themes can well be linked with the current state of sufferings in Kashmir, and Kashmiris yearning for freedom.

The reference to Mughal occupation of Kashmir is also important, suggesting people's stiff resistance and battles against Mughals' several attempts of annexation of the state and their occupation before the Mughals managed to occupy the state in 1586 (Ahmad, 2017)."Mughal King Akbar invited and imprisoned Kashmir's last king Yousuf Shah robbing Kashmiris of their freedom. Till 1586, Kashmir was known as a big state. Akbar occupied Kashmir cunningly and Kashmiris have never forgotten this wound" (Mehjoor, 2007, p. 19).

It is important to mention here that Kashmiris' resistance was not confined to the Mughal occupation alone, rather theyresisted all the foreign occupation including those of Afghans and Dogras.The following remark of the protagonist of Dahshat Zadias she leaves her office defying all the dangers outside at the height of violence in Kashmir hints upon Kashmiris' love for freedom:
"Rebelliousness is in (our) blood" (p. 23).

Dahshat Zadimakes a large number of historical references from around the time of partition and after that. For instance, the arrest of Sheikh Abdullah on August 8, 1953 holds political significance in the modern history of Kashmir and this reference is also made in the novel.

"Father is probably watching a picture of the future which is blurry or perhaps he is remembering that time of 1953 when he had to go through fear and misery after Sheikh Abdullah's arrest" (p. 10). It was believed that Sheikh Abdullah wanted to accede the state to Pakistan and he got arrested at the instance of the then Indian Prime Minister Pandit Jahawal Lal Nehru.

Another reference to history rather triumphantly mentions how the people's rebellion assisted by the tribal fighters forced the then ruler of Kashmir to flee from Kashmir in the post 1947 context. "We forced the Maharaja to exit the valley in the dark of the night" (p. 155).

Harlow sees resistance literature as situated in a specific historical context and liberation struggle.The historical references of partition, characters' quest for freedom since 1947, Sheikh Abdullah's arrest due to his alienation with India and people's anger and resentment against the post-1989 developments suggest that Dahshat Zadi is situated within a specific context and liberation struggle that in its current phase was triggered in 1989. This situatedness in literature is meant to make certain demands on the part of its reader. According to Harlow: "Essential then to the narratives of resistance is the demand they make on the reader in their historical referencing and the burden of historical knowledge such referencing enjoins" (1987, p. 20).

With these historical references to real past events, Dahshat Zadialso blends fact and fiction to augment and enhance the reality and its lived experiences. The settings of the novel, its characters, places and incidents are employed to signify matter of fact illustration of the circumstances of the post-1989 Kashmir. Harlow 
observes that resistance literature challenges the conventional literary divisions and hierarchies. Blurring the boundaries of fiction and memoir,Dahshat Zadi paints a painful but realistic picture of Kashmir and Kashmiris and in doing so resists the constant manufacturing of statist narratives. The novel is a real story of a noted Kashmiri journalist who worked with All India Radio and BBC Urdu. The novel is full of real incidents that took place in the state of Jammu and Kashmir. Every section of the novel starts with a little description of the significant incidents of post-1989 scenario. For instance, the first blast in 1988 at the house of a police officer (p.7) (this incident is considered the formal beginning of armed uprising in Kashmir), the appointment of Jagmohan as Governor of Jammu and Kashmir(p.21), the formal beginning of reign of terror and repression by security forces, 10,000 Kashmiri youth crossing the LoC to get training from Pakistan (p. 39), exhodus of Kashmiri pandits (p. 44), kidnapping of Rubaiya Sayeed, introduction of draconian laws particularly Armed Forces Special Powers Act and Public Safety Act(p.73), Kunun Poshpura gang rape in which around 100 women were raped by Indian security forces (p. 142), the phenomenon of Ikhwanis, the Kashmiri militant collaborators with Indian security forces, the killing of the Director of Doordarhan in Kashmir, Lassa Kaul, Papa 2 interrogation (p. 53) are all real incidents that marked the harrowing decade of post-1989 scenario.

Besides documenting these key incidents of post-1989 Kashmir, it also depicts sociopolitical realities of the time. For example, the political divide in the state due to which the followers of Sheikh Abdullah were termed as Lions while those of Mir Waiz Kashmir Maulvi Faroorq as Bakar (p.14).There is a strong perception among the researchers that the creation of Bangladesh, Islamic Revolution in Iran, and defeat of USSR in Afghanistan had had fallout on Kashmir's freedom struggle. The author of Dahshat Zadialso captures this:
The Sher-Bakra fight lost some of its steam after Pakistan lost its eastern wing in 1971 in a war that resulted in the creation of Bangladesh. People were disillusioned and disappointed with the idea of a separate homeland for Muslims. However, feelings of religious identity were rekindled when the Afghanistan jihad brought the Soviet Union to its knees, and Islamic revolution toppled the USbacked Reza Shah Pahlavi's rule in Iran. This began raising the consciousness of Kashmiris with regard to the humiliation they believed they were constantly suffering at the government's hands. The new armed struggle owed its inspiration to Islamic awakening throughout the Muslim world. (p. 13)

Similarly, Jagmohan Malhotra who was also the leader of BJP appointed governor in Kashmir when the freedom movement became popular in the valley. As a protest against his appointment, Dr Farooq Abdullah resigned in 1990. Around the same time, Kashmiri pandits who were sympathetic to Indian union were given important offices in Kashmir and the local Muslim officers were transferred to other Indian states. These all are the factual happenings of that time and the novel depicts themwith such precision that it reads as if it is a work of history (e.g., see p. 23).

Literary narratives are usually taken as the works of art and analyzed accordingly. Resistance narratives, on the other hand are heteroglossia in nature, representing a variety of discourses, perspectives and voices, thus becoming not only the works of art and literature but also of history, ideology and politics (Harlow, 1987, p. 98).Dahshat Zadi can also be termed a heteroglossia narrative as it is polyphonic in regard toideology, history, society and politics. As stated above, the numerous historical references in the novel make it a work of history.

The novel also qualifies as a work of journalism. It incorporates the real incidents occurred in the wake of 1989. They include the first blast at the residence of a senior police officer in Kashmir, ushering in the formal beginning of armed struggle in Kashmir, and the appointment 
of Jagmohan Malhotra the governor of Kashmir, unleashing a wave of unabated terror, violence and torture, gross human rights violations by the security forces and Ikhwanis, India backed militants, and other incidents capturing the state of affairs during 1990s in Kashmir.

Similarly, the novel can also be termed as the work of sociology as it illustrates the social milieu of Kashmir and as to how this conflict affected the social fabric society. The disturbing life of the protagonist with her husband, the fear and uncertainty among all sections of society, marginalization of women, pangs of the mothers whose sons have either crossed the border to join militancy or were arrested or killed in front of their eyes. The disappearance of Sadia's son and Fareeda's husband, the brutal killing of the son of Auntiji, and the killing of Shaista symbolize the suffering of women in Kashmir.

For Harlow, another characteristic of resistance narrative is that it is collective in nature (1987, p. 119). The protagonists and the characters are not just individuals; rather they stand for the lives of the people living in a human society. “... people's collective relationship to the cause they are fighting for, to the land they live on, and to the national identity they share makes collectivity an essential feature of resistance literature as it calls for a collective action in order to achieve the political, social and economic changes it struggles for" (Allaham, 2009, p.26).

Dahshat Zadi is apparently a story of a family, unpleasant relations of the protagonist with her husband, her experience of being a journalist in the conflict zone but it is the collective story of the post-1989 Kashmiri society. The novel paints the harrowing portrait of the contemporary Kashmiri society. It depicts the collective plight of pro-freedom Kashmiri families, the challenges faced by Kashmiri women pertaining to their life, family, work and dignity, and the trauma and fear the whole society is gripped in. It is a collective protest against the occupation of the hapless people and their resentment against Indian occupation. The story of Fareeda, Auntiji, and Sadia is the account of thousands of Kashmiri mothers and wives who have lost their children or husbands and most of the times are unaware whether their loved ones are alive or dead. They remain in perpetual agony and unhealable pain. Similarly, the father of the protagonist and her sisters arerepresentative characters of many Kashmiris who are the eyewitnesses of India's politics, and have a deep seated desire to get freedom from India but largely remain silent due to fear of the unthinkable.

The novel also represents the act of silencing perpetrated by the oppressors in KashmirThough these silent voices sometimes speak louder than the articulate ones and in their own way serve as expressions of resistance against the oppressor. The desolatedvalley speaks of terror."There is not even a shadow of the people of the neighborhood as if the valley has been put to a deep sleep. The deserted and silent streets are spreading terror" (Mehjoor, 2007, p. 45).

Since 1990 especially after the appointment of Governor Jagmohan and extension of black laws to Kashmir such as Armed Forces Special Powers Act and Public Safety Act, the valley has turned into a killing field consuming thousands of people killed, maimed, disappeared and incarcerated. At one point in the narrative, the protagonist grumbles about everyone's silence over the conduct of her husband (p. 135). But her character, at this point, seems synonymous with the Kashmir valley and the world's apathy and silence over the sufferings of the people of Kashmir."Why is the whole world silent over the circumstances I am going through? Why don't my relatives speak? Why don't they question my silence?" (p. 135). This silence of the world community and the global organizations speaks volumes of the world's apathy and indifference.

Representing the deep-rooted resentment of Kashmiri people against Indiathat is intensifying with each passing day is a strategy of resistance employed by the author. Also, this resentment is not a recent phenomenon, rather it is rooted in the India-Pakistan partition when India usurped the state of Jammu and Kashmir through 
political intrigues and machinations: "All of us hate India. It will not be any exaggeration if I say that this hatred came as our mothers breastfed us. This hatred is not decreasing but is multiplying with every passing day" (p. 10).

Similarly, in another section in the novel the steely resolve of the women of the state has been represented who vowed to fight for the next hundred years to get freedom from India. It is important to mention here that this resolve is demonstrated shortly after one of the horrendous massacres, known as Kunun Pospura incident, in the recent Kashmir's history occurred. "A woman in headscarf is carrying a photo of the girl who was raped. This woman is loudly telling other women: 'those wolves tore her clothes in front of her father. These animals butchered this innocent girl and raped her in front of her father...Indians think they can weaken us by these cruelties. But we are fighting for freedom and we will continue to do that for a hundred years" (p. 153).Through such instances the novel echoes their deep-rooted quest for freedom and unflinching resolve and resistance against the oppression and occupation of their land.

The father of the protagonist while advising her daughter to develop ties with her husband on the basis of dignity and respect, quickly gravitates towards India-Kashmir relationship which was established by force and usurping the rights of Kashmiris. This hints upon a breakup that will result into freedom (see p. 30).India claims that the state of Jammu and Kashmir acceded to India on $26^{\text {th }}$ October 1947 through the Instrument of Accession signed by the then ruler of Kashmir Maharaja Hari Singh. Besides this document, India continues claiming that the State Assembly of Jammu and Kashmir had formally ratified Kashmir's accession to India and that the participation of Kashmiri in every state assembly elections since its formation suggest that the people of Kashmir are happily wed-locked in this relationship with India. However, the remarks of the father of the protagonist's in Dahshat Zadiindicate that even the first generation of Kashmiris who were supporting Sheikh Abdullah (who later compromised with India) challenge India's claim over Kashmir and its illegitimate relations with the state of Jammu and Kashmir.

The novel also employs various symbols as an important strategy of resistance. The protagonist equates herself with a fly caught in a door hinge. "I saw a hole in the window in which a fly was caught up and flapping its wings to go free" (p. 33).Though the fly is equated with the protagonist as she is caught up in turbulent domestic relations, but it is synonymous with Kashmir that is caught up in the web of geopolitical imperatives, leaving the hapless inhabitants to continually broil in the conflict. This also questions the geopolitical structure, the powerful countries and global institutions particularly the intergovernmental body of the United Nations and their apathy to the human sufferings of the people of Kashmir for over seven decades.

At another point, the writer mentions the smell of rotten meat across Sulemain Mountain as a thinly veiled reference to the dead bodies dumped in mass graves along the Line of Control. "Whenever Auntiji went on a walk towards this mountain, she came back to say that the path smelled of rotten meat" (p. 305).Both the husband of Fareeda and the son of Aunty were brutally murdered by the security forces.In Kashmir, hundreds of youth who got killed by the security forces were either buried in unmarked graves near the border or their bodies were littered around.

Another section describes Kashmir's climate, referring to the security climate of the valley."The weather of Kashmir has suddenly changed. Days are dry, hot and dusty, nights in terror, airless and damp. A Kashmir that was once known as paradise is so hot this year that people have begun calling it hell" (p. 26).

It is, in fact, the politico-security climate of the valley that has undergone seismic shift, turning the valley from a pleasant resort to a hell. This shift occurred when the valley of Kashmir got under the grip of violence. Killings of Kashmiris, explosions, abductions, torture at 
various interrogation centers, rapes of Kashmiri women by security forces and crackdowns became the order of the day. The litany of these tragic incidents turned the proverbial paradise of Kashmir into a hell.

Chinar, another important cultural symbol in the context of Kashmir, has also been used in the novel representing multitude of meanings.

In the days gone by, our elders would constructively use these trees for their routine gettogethers, for discussions, for easing and relieving themselves after hard labors under the umbrage and shade of these trees. They would also enact and stage religio-cultural activities like the Bhand Pather (traditional Kashmiri folk entertainment), preparation of the Peer Khairaat/ Bhandaar (local religious feast) under the domain of the Chinar tree. (Malik \& Shah, 2017)

Besides the cultural association with Chinar tree, its leaves, especially during autumn when they turn yellow with a shade of red, also symbolize fire. People of Jammu and Kashmir have always resisted against the occupation of the state by the foreign rulers. This is perhaps the same rebellious spirit for which the poet of the East, Muhammad Iqbal (who also happens to have a Kashmiri ancestry), refers to in one of his famous couplets:

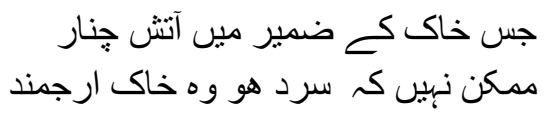

(The heart in whose conscience burns the oak's fire,

You cannot cool down that noble heart's fire.)

However, when the Kashmir has turned into a garrison due to heavy military presence and violence, these cultural events disappeared, and the cultural side associated with Chinar ceases to exist in the valley. The moment the shade of Chinar virtually ceases to exist in the valley, the sizzling sun starts burning the people of Kashmir. "Where I am sitting, the shade of the chinar has vanished. I am burning in the scorching sun. Sharp sunrays, like a triple spear, are entering my eyes and blinding me. As if we are under two interrogations: one by the military and the other by the sun" (Mehjoor, 2007, p. 141).
The scorching heat symbolizes the litany of violence in Kashmir. It is not the protagonist who is burning in this blaze but the whole vale of Kashmir is boiling in it. The symbol of Trishul is very deftly incorporated by the author. It is a triple spear weapon used by Hindu militant outfits in acts of violence. These acts have been considerably increased after BJP's ascension in power in India since 2014 as well as in Kashmir as the coalition partner of People's Democratic Party.Trishul is being used as a metaphor blinding the protagonist symbolizingthe blinding of people by putting them under curfew to not allow them to witness whatever happened on streets. This also reminds us of the recent incidents of mass blinding in Kashmir in which hundreds of youth, women and children got blinded through pellet guns. This mass blinding was done in Kashmir in 2016 when the BJP was ruling both India and the erstwhile state of Jammu and Kashmir

As all resistance narratives challenge the dominant discourse, Dahshat Zadi also defies the mainstream Indian media discourse toeing the Indian state's line that the turbulent situation in Kashmir is primarily caused by the Kashmiri fighters. On the other hand, the local Kashmiri media is not free enough to speak the truth. "Indian media is extremely patriotic. No matter what the extent of bloodshed, destruction and decay in Kashmir, the media would put all the blame on militants giving a safe passage to the security forces. I want to take a chance to expose this but there is little hope that it will be published" (p. 188).

The protagonist of the novel is asked by an Indian daily to write an article on the killing of Saira, a close friend and colleague of the author, but she believes that the paper might not publish her version. So, she decides to write about her death and not the circumstances that led to her killings. "I wrote some pages for the Indian Daily but they are more about Saira's passing away than the circumstances" (p. 188).

\section{CONCLUSION}


The novel Dahshat Zadi is apparently a life story of a Kashmiri journalist, her professional and domestic life narrating perils of a Kashmiri woman but as a reflection of "everyday encounters between persons and their cultural context" (Lawrence \& Dodds, 2017, p. 74), it isa case of resistance narrative in the context of Kashmir. Our discussion shows that this work of fiction is featured with defining parameters and representative literary strategies of resistance. Therefore, on the one hand it contributes to the broader resistance movement in Kashmir and on the other hand it is linked with the tradition of resistance literature.

Earlier, the story of post-1989 Kashmir was mediated mostly by those who were not the participant observers of the conflict; they did not live through the conflict and the perils and predicament it unleashed upon the inhabitants. With the publication of this Urdu novel a new wave of resistance narratives has begun in Kashmir. This not only brings to fore the human dimension of the conflict, but also resists the Indian occupation, the state oppression, the overwhelming militarization and depriving the people of their right to life, safety and dignity. The author's employment of the strategies of resistance suggests that art has the power to aestheticize and carry the bitter human realities and experiences.

\section{REFERENCES}

[1] Abbas, R. (7 December 2017). Writers must register protest by resistance literature, The Rising Kashmir (December 7, 2017), retrieved from http://www.risingkashmir.com/news/writ ers-must-register-protest-by-resistanceliterature-rahman-abbas.

[2] Abbas, F., Jalil, M. K., Zaki, H. N., \& Irfan, F. (2020). Implicit measure of language attitude: study of Punjabi native speakers by using matched guise technique. International Journal of Innovation, Creativity and Change, 13 (1), 194-206.
[3] Ahmad, K. B. (2017). Kashmir Exposing the Myth behind the Narrative, New Delhi: Sage.

[4] Allaham, A. M. (2009). The Short Story as a Form of Resistance: A Study of the Short Stories of Ghassan Kanafani, Ngugi wa Thiong'o, and Alice Walker, Newcastle University, UK.

[5] Beverley, J. (2004). Testimonio: On the Politics of Truth. London: University of Minnesota.

[6] Bhat, J. I. (2016).Romance, Freedom and Despair: Mapping the Continuities and Discontinuities in the Kashmir English, University of Ohio.

[7] Dar, A. B., Mir M., \& Kabir, Q. A. (2014, Trans) The Gift from Hijaz. Lahore: Iqbal Academy Pakistan.

[8] Flynn, E. A. (1996). Writing as Resistance. JAC, 16(1), pp. 171-176.

[9] Harlow, B. (1987). Resistance Literature. New York: Methuen.

[10] Hyder, U. (2017). The Pianist as a Testimonial Narrative. International Journal for Social Studies, 3(9), 104-110. https://doi.org/10.26643/ijss.v3i9.6465.

[11] Lateh, N. H. M., Shamsudin, S., Singh, M. K. S., \& Said, S. M. (2017). Is Receptive Vocabulary Knowledge a Predictor for English as a Second Language Learners' Level of Speaking Performance?. Advanced Science Letters, 23(4), 2907-2910.Mehjoor, N. A. (2007). Dashat Zadi. Lahore: Feeroz Sons.

[12] Lawrence, J. A. \& Dodds, A. E. (2018). Toward a Psychology of Resistance. Integrative Psychological and Behavioral Science, 52(1), pp. 67-76. doi:10.1007/s 12124-017-9411-9

[13] Malik, A. N. \& Shah M. A. S. (May 10, 2017). Chinar a symbol of unity of people, The Rising Kashmir, Retrieved from

http://www.risingkashmir.com/news/chin ar-a-symbol-of-unity-of-people. 
[14] Mora, R. A. (2015). Key Concepts in Intercultural Dialogue, 45. Retrieved fromhttp://centerforinterculturaldialogue. org.

[15] Mora, R. A. (2015). Key Concepts in Intercultural Dialogue, No. 45, 2015, Retrieved from https://centerforinterculturaldialogue.files .wordpress.com/2015/01/kc45testimonio.pdf.

[16] Noorizan, A. D., Shamsudin, S., Manan, A. A., \& Singh, M. K. S. (2017). Frequency Analysis of Academic Words in Malaysian Secondary School English as Second Language Textbooks: A Corpus Study. Advanced Science Letters, 23(4), 3124-3127.

[17] Premi, B. D.(1992). Jammu Kashmir Mein Urdu Adab Ki Nashunama, Srinagar: Deep Publications.

[18] Tateo, L. (2017). Seeing imagination as resistance and resistance as imagination. In N. Chaudhary, P. Hviid, G. Marsico, \& J. W. Villadsen (Eds.), Resistance in everyday life: Constructing cultural experiences (pp. 233-245). Singapore: Springer. https://doi.org/10.1007/978981-10-3581-4_17.

[19] Waheed, M. (2011). The Collaborator. London: Penguin. 